\title{
Cloaking Neo-Imperialism in the Shadows of Human Rights and Liberal Peacebuilding
}

\author{
Saadatu Salisu Matori \\ Lecturer in Law with the Yobe State University, Nigeria \\ Abubakar Bukar Kagu \\ Senior lecturer in Law and Director CRCDHS, Yobe State University, Nigeria
}

\begin{abstract}
The concept of intervention to curtail humanitarian crisis in conflict zones has generated a great deal of polemics on the matters of state sovereignty, human rights, democracy and even the legitimacy of liberal peacebuilding. These discussions often include the justification or otherwise of both political and militarised interventions. While interventionism has become the most common approach by world powers, the concept of liberal peace building with its cloaked connotation of fostering and sustaining tranquillity and curtailing humanitarian crisis is seen by many as lacking in the not only the protection of people but also in ensuring sustainable peace. The view of some scholars is that, intervention in the name of humanitarianism raises so many questions as world powers continue resorting to militarised approaches that do not translate to the welfare of those they claim to protect. Instead, the outcome has been largely a convoluted and surging circle of crisis across many corners of the world.
\end{abstract}

Keywords: Conflict, Intervention, Humanitarian, Law, Protection, Sovereignty

DOI: $10.7176 / \mathrm{JLPG} / 88-08$

Publication date: August $31^{\text {st }} 2019$

\section{Introduction}

The continues eruption of conflicts around the world has resulted in series of attempts to build certain international humanitarian and legal codes to address the difficulty of civilians caught in war. Notable attempts in recent history include The Hague Draft Rules of Aerial Warfare (1923), and the 1977 Additional Protocols to the Geneva Convention. These resolutions and conventions reflect some of the global commitment to create a framework that will protect and assists those in need of help and humanitarian aid. ${ }^{1}$ Despite the need to protect civilians from armed conflict, there has a been controversies in relation to the legitimacy and effectiveness of such interventions. This is mainly due to the shift in approach that brings to the fore several institutional and structural concerns, particularly about the rights and wrongs of imposing particularized understandings of conflicts and also in trying to justify the 'grounds and the location of authority for the use of force to intervene. ${ }^{2}$ intervene. ${ }^{2}$ Evidently, most of the interventions that led to more crisis were ones pursued through militarised means. From Iraq to Syria, to Libya, to Bosnia to Somalia, the polemics were enormous. ${ }^{3}$ One of major aftermath of this was the complexity not only of the conflict itself but also about the blurring distinction between the doctrine of state sovereignty and non-interventionism principles. What it means to justify an intervention and offer aid or protection to civilians and vulnerable groups has been brought under serious scrutiny, especially in international law. While the idea of humanitarian intervention is, in principle, one that advocates for a more politically conscious aid with a broader goal of making such aid to include both military and diplomatic measures that protect civilians and build platform for strategic long-term conflict-resolution mechanisms, ${ }^{4}$ the construction and narratives in contemporary populist political discourse has incidentally disrupted these guiding principles, resulting in convoluted and upsetting inaccuracies in accounts and statements relating to protection of civilians and humanitarianism. Hence, the now growing idea of liberal peace building which is also one that will continue to raise many questions in law and politics.

\section{The Doctrine of Liberal Peace Building.}

The principle of liberal peace building revolves around the notion that international peace and individual rights are concepts that can best be achieved through broad-based frameworks whereby democratic states take a lead in

\footnotetext{
${ }^{1}$ Gade, E. K. (2010). Defining the Non-Combatant: How do we Determine Who is Worthy of Protection in Violent Conflict?. Journal of Military Ethics, 9(3), 219-242.

${ }^{2}$ Reeds in Glanville, L. (2013). In defense of the responsibility to protect. Journal of Religious Ethics, 41(1), $169-182$.

3 Annan, K. (1999). Intervention. Medicine, Conflict and Survival, 15(2), 115-125; Harff, B. (1992). Bosnia and Somalia: Strategic, Legal and Moral Dimensions of Humanitarian Intervention. Philosophy and Public Policy Quarterly, 12(3/4), 1-7; Tesón, F. R. (2006). Eight principles for humanitarian intervention. Journal of Military Ethics, 5(2), 93-113.

${ }^{4}$ Fox, F. (2001). New humanitarianism: does it provide a moral banner for the 21 st century?. Disasters, 25(4), $275-289$.
} 
ensuring the interests of common humanity. ${ }^{1}$ In semblance to the doctrine of responsibility to protect, the idea of liberal peacebuilding is premised on the notion to 'institutionalize a new international security framework which emphasizes the development of international norms and the promotion of democracy and human rights. ${ }^{2}$ The problem with liberal peace building according to Richmond is that the concept is framed towards a one-size-fitsall paradigm with different components such as liberal democratic order, free market reform and development, as well as conceptualisations of human rights and civil society. Yet, as Chesterman argues, 'peacebuilding is now generally accepted as an important tool in the conflict resolution toolkit. What is often far from clear, however, is exactly what type of peace is to be built, how and at the expense of what?. ${ }^{3}$ In truth, the contemporary structural underpinnings of Western peacebuilding methods limit the space to explore other alternatives approaches, ${ }^{4}$ making the whole approach to assume connotations that are akin neo-imperialism. Even when the term "local ownership" is used by the international community, rather than strengthening local institutions and promoting them, the local community is often side-lined and denied ownership of the process. Hence, the criticism on whether this idea springs from a realist enterprise designed to contain conflict or even resolve the underlying sources of such conflict and engage with grassroots actors and issues. ${ }^{5}$ In a legitimate passion, critics often ask whose vision of peace is being promoted, especially when an intervention by world powers become militarised, leading to the kind of catastrophe that characterised the intervention in Iraq, Libya, Yemen etc.

The theory of liberal peace challenges both the realist view that sees war as an inevitable result of shifting balances of power in an anarchistic world, and the English School approach, which emphasizes the consensual status quo framework of the United Nations Charter. ${ }^{6}$ Many scholars have criticised this concept, asking whether liberal peace is viable and legitimate means to sustain state building, or just another strategic approach towards a new form of neo-imperialist hegemonic control. ${ }^{7}$ Questions were also raised whether liberal peacebuilding is a realist strategic enterprise meant to contain conflict and its wider repercussions, or does it address objectives such as emancipation and social justice, and if so, how?

Another contention is in reference to the complexity of underpinning the agenda for liberal building within the framework of international political discourse. This debate on the validity of humanitarian intervention highlights the paradox of matching moral authority with legal and political legitimacy. ${ }^{8}$ This question becomes even more complex in contemporary international relations where the framework of international law puts the principality of state sovereignty at the top of international relations. This prevailing doctrine does not often justify interventionism. Furthermore, the experience of most non-western states, who were the victims of interventions have questioned the moral justification for interventionist practices and have expressed concern that this paradigm in global politics undermines their rights of sovereignty, ushering in a more coercive, Western-dominated, international order. ${ }^{9}$ The outcome of the 2005 World Summit, for instance, suggests that most states do not consent to a global order that leans towards the concept of liberal peace building. What was instead contained, particularly in Paragraphs 138 and 139 of the summit's outcome document stated is that each individual state has the responsibility to protect its population from war crimes, genocide, ethnic cleansing and crimes against humanity. ${ }^{10}$ This responsibility includes the prevention of such crimes and not inciting them through any means. The outcome document also presents a new voice of concern and scepticism, with a broadbased consensus among participants that host states had the primary responsibility to protect, and the participants also insist on the notion that the P-5 should voluntarily limit their use of the veto. ${ }^{11}$ The paradox, however, is the content of the document which states that the international community has a responsibility to intervene when states failed to ensure the security and rights of their citizens. This commitment was seen by most observers as

\footnotetext{
${ }^{1}$ Evans, T. (2001). If democracy, then human rights?. Third world quarterly, 22(4), 623-642; Walt, S. M. (1998). International relations: one world, many theories. Foreign policy, 29-46; Chandler, D. (2004). The responsibility to protect? Imposing the 'liberal peace'. International peacekeeping, 11(1), 59-81.

2 ibid

${ }^{3}$ Roberts, A. (2001) "Humanitarian Issues and Agencies as Triggers for International Military Action." In Civilians in War, edited by Simon Chesterman, pp. 177-196. Boulder: Lynne Reinner; Paris, R. (1997). Peacebuilding and the limits of liberal internationalism. International security, 22(2), 54-89.

${ }^{4}$ Mac Ginty, R. (2008). Indigenous peace-making versus the liberal peace. Cooperation and Conflict, 43(2), $139-163$.

${ }^{5}$ Paris, R. (1997). Peacebuilding and the limits of liberal internationalism. International security, 22(2), 54-89.

${ }^{6}$ Chandler, D. (2004). The responsibility to protect? Imposing the 'liberal peace'. International peacekeeping, 11(1), 59-81. Sebastian, L. C., \& Roberts, C. B. (2015). 'Consensual'Regional Hegemony, Pluralist-Solidarist Visions, and Emerging Power Aspirations. In Indonesia's Ascent (pp. 335-347). Palgrave Macmillan, London.

7 Paris, R. (1997). Peacebuilding and the limits of liberal internationalism. International security, 22(2), 54-89; Rupert, M. (2005). Resisting globalisation and war in a neo-imperial moment. Critical Theories, International Relations and'the Anti-globalisation Movement': The Politics of Global Resistance, 18, 36; Escobar, A. (2004). Development, violence and the new imperial order. Development, 47(1), 15-21.

${ }^{8}$ Chandler, D. (2004). The responsibility to protect? Imposing the 'liberal peace'. International peacekeeping, 11(1), 59-81; Chandler, D.

(2010). R2P or Not R2P? More State building Less Responsibility. Global Responsibility to Protect, 2: 161-166.

${ }^{9}$ ibid

${ }^{10}$ Bellamy, A. J. (2006). Whither the responsibility to protect? Humanitarian intervention and the 2005 World Summit. Ethics and International Affairs, 20(2), 143-169.

${ }^{11}$ Stahn, C. (2007). Responsibility to protect: Political rhetoric or emerging legal norm?. American Journal of International Law, 99-120.
} 
synonymous of what liberal peace building entails.

Arguably, liberal peace building has already been marred by the politics of new humanitarianism. As Gray stated in the Guardian that the general optimism with the idea of liberal interventionism is dead. ${ }^{1}$ Principally, the wars in Iraq and Libya have cause crisis of both confidence and credibility for proponents of intervention. Although proponents still maintain that liberal intervention is a form of biopolitics aimed at transforming the populations of ineffective states and a strategy to insulate the society from the permanent crisis on its frontiers. ${ }^{2}$ What is most evident is that the world is caught up in a crossroad between the need to intervene and secure the lives and rights of populations caught up in conflict and the growing econo-political agenda that often resonates with these interventions, leading to even more wide spread crisis and quandaries.

There is today a growing opinion that most of the recent interventions, and the claim for reform of governance is mostly guided by the clandestine interest of actors involved in such interventions. The claim that interventions are to ensure peace have come under intense scrutiny. The control of the process according to Richmond 'rests upon a combination of inducement, consent, and cooperation, occasionally verging upon the coercive, or even the outright use of force. ${ }^{3}$

Although many outside observers tend not to question the validity of liberal peace as it is often projected as a moral action aimed at democratisation, development, and economic reform, the recipients almost all the times tend to be suspicious of outsiders' objectives. ${ }^{4}$ Hence, as Goodhand suggests, the question of justification could best be argued when all strands are taken into consideration, especially the interest of the recipients. Nevertheless, aspects on peace and security may sometimes be subjective, because both are intimately bound up with local definitions of security. He pointed out how academics and policy-makers have tended to focus on internal problems but emphasised more on the supremacy of external solutions. ${ }^{5}$ This conception must therefore be rebalanced in a way that greater focus should be giving to external causes while searching for internally generated solutions. ${ }^{6}$

\section{A New Form of Neo-Imperialism}

Because of the growing political dimension that most recent interventions have taken, many critics think it has become neo-imperial tool for strong nations against weak ones. ${ }^{7}$ Referring to International law doctrines, Mamdani raised similar criticism, especially with regards the political trajectories and the aftermath of recent interventions in Africa. He cited for example the war in Darfur, arguing that the West often intervenes not to attend to the challenges of civilians but to solidify their economic and expansionist interests. In the end, most of these engagements turn weaker states into regions that are solely dependent on the international community, 'with the knock-on effect that their citizens, too, are transformed from autonomous political actors into wards of the international community. ${ }^{8} \mathrm{He}$ further states that the new global regime of responsibility to protect bifurcates the international system between sovereign states whose citizens have political rights, and de facto trusteeship territories whose populations are seen as a population in need of external protection. ${ }^{9}$

Some of these critics also link interventionism with the politics of the UN and the ICC, claiming that these so-called global institutions are also complicit in promoting a partial, Western dominated world order. This also reflects the opinion of Kearny on the Israeli Palestinian conflict. He maintains that to speak of ideas such as the responsibility to protect as applying to Palestinians at all, one must accept the fact that there is a need to protect a vulnerable population against genocide, war crimes, ethnic cleansing, or crimes against humanity. ${ }^{10}$ Yet, many people and institutions, such as Canada, have refused to acknowledge that there is an existing crime against humanity been perpetrated by Israel. ${ }^{11}$

This criticism also goes further to indict international institutions as complicit in the ongoing neo-imperial agenda of western powers. Mandami for instance, gave instances of how the arbitrary way in which the use of force by states such as Sudan becomes criminalised, while the use of force by Western allies such as in Uganda

\footnotetext{
${ }^{1}$ Gray, J., (2007). 'The death of this crackpot creed is nothing to mourn', The Guardian 31 July.

${ }^{2}$ Duffield, M. (2005). Getting savages to fight barbarians: development, security and the colonial present: Analysis. Conflict, Security and Development, 5(2), 141-159.

${ }^{3}$ Richmond, O. P. (2006). The problem of peace: understanding the 'liberal peace'. Conflict, Security and Development, 6(3), 291-314.

${ }^{4}$ ibid

${ }^{5}$ Goodhand in Cooper, N. (2007). Review article: On the crisis of the liberal peace: Resources. Conflict, Security and Development, 7(4), 605-616.

${ }^{6}$ ibid

${ }^{7}$ Ayoob, M. (2001). Humanitarian intervention and international society. Global Governance, 225-230.

${ }^{8}$ Mamdani, M. (2010). Responsibility to protect or right to punish?. Journal of Intervention and Statebuilding, 4(1), 53-67.

${ }^{9}$ Heathershaw, J. (2008). Unpacking the liberal peace: The dividing and merging of peacebuilding discourses. Millennium, 36(3), 597-621;

Mamdani, M. (2010). Responsibility to protect or right to punish?. Journal of Intervention and Statebuilding, 4(1), 53-67.

10 Kearney, M. (2014). In Palestine, R2P Isn't Dead. It Could Never Have Existed. Available at: http://justiceinconflict.org/2014/07/22/palestine-israel-and-r2p-a-symposium/

11 ibid
} 
is accepted and normalized. ${ }^{1}$ In Uganda, for example, nearly a million people were forcibly displaced, but the International Criminal Court (ICC) only charged the leadership of the Lord Resistance Army (LRA), but not that of the government which is an ardent ally of the West. ${ }^{2}$ Similarly, in Sudan, the ICC charged officials of the Sudan Government for alleged war crimes but failed to indict any of the rebel leaders, and in Congo, the ICC was extra ordinarily reluctant to investigate or even discuss the links between the armies of Uganda, and the ethnic militias that have been widely accused of systematic killing of civilians. ${ }^{3}$ Falk also states that the concept is more like the Mississippi River, which flows only from North to South. Uruguay, he says, cannot use B-52s fighter jets to punish Britain for its policy in Northern Ireland, nor could Yemen launch cruise missiles on Washington out of solidarity with the oppressed in U.S. cities. ${ }^{4}$ Hence, there is the need to be cautious about a right that can be enjoyed only by the powerful..$^{5}$ Although there are various arguments that tend to support the idea of intervention to protect vulnerable populations, the challenging question however remains on whether or not the principles can be successfully rolled out across the world on the basis of impartial and justifiable global consensus. ${ }^{6}$

\section{Conclusion.}

The last two decades has seen the reconceptualising of the idea and practice of intervention, mostly on the assumption that there is the need to build a common global consensus to redress issues relating to protection of civilians from the mass atrocities of conflict. Taking into account the mature an outcome of interventions in conflict, the grounds for such interventions, which were supposedly to reside in international law have often been thwarted. The main challenge today is that the changing nature of global politics has blurred the borderline between the right of people to be protected and the legitimacy of powerful democratic nations to intervene to ensure such protection. In the end, this complexity has added to the vulnerability of caught in conflicts, particularly those who are either targeted by their own state or those who the state fails to protect. These has added to the plight of civilians in many parts of the world and the confusion among the international community to make consensus on precise legal and political determinations of when and how to intervene for the protection of vulnerable population caught in conflict or oppressive regimes. Despite these legitimate question in internal law and relations, interventionism now seems far more firmly established as a world order in ways that threatens the principles of sovereignty, territorial integrity and even the security of nations and regions. One of the most important debate going forward is not to delegitimise intervention, but to advocate for and strengthen the idea of humanitarian intervention and the commitment to protect civilians in ways that respect existing rules of international law and treaties by insisting against unilateral and treating such unilaterality as violation of state's sovereignty and international law.

\footnotetext{
${ }^{1}$ Mamdani, M. (2010). Responsibility to protect or right to punish?. Journal of Intervention and Statebuilding, 4(1), 53-67; Branch, A. (2007). Uganda's civil war and the politics of ICC intervention. Ethics \& International Affairs, 21(2), 179-198; Branch, A. (2007). Uganda's civil war and the politics of ICC intervention. Ethics \& International Affairs, 21(2), 179-198.

${ }^{2}$ Chimni, B. S. (2017). International institutions today: an imperial global state in the making. In Globalization and International Organizations (pp. 41-78). Routledge; Mamdani, M. (2010). Responsibility to protect or right to punish?. Journal of Intervention and Statebuilding, 4(1), 53-67.

3 ibid

${ }^{4}$ Falk, R. (2000), Human Rights Horizons: The Pursuit of Justice in a Globalizing World. London: Routledge.

5 ibid

${ }^{6}$ Johnson, J. T. (2006). Humanitarian intervention after Iraq: just war and international law perspectives. Journal of Military Ethics, 5(2), $114-127$
} 